\title{
Birlikte Yaşamak Mümkün Mü?: \\ Okur Yorumlarında “Suriyeli Sı̆̆ınmacı” Söyleminin İnşası
}

Cemre Bolgün a, b, Gülten Uçan c

Özet

Suriyeli sı̆̆ınmacıların geri dönme ve Avrupa'ya geçme umutlarının tükenmesi ile birlikte sosyal uyum konusu önem kazanmıştır. Çalışmanın amacı, birlikte geçirilen yaklaşık sekiz yılın ardından sosyal uyum açısından gelinen aşamayı, okurların web üzerinde yayınlanan haberlere yaptıkları yorumlara dayanarak değerlendirmektir. Araştırma, fenomenolojik tipte betimleme amaçlı niteliksel bir çalışmadır. 01.05.2015 ile 30.04.2019 tarihleri arasında yayınlanan haberler hakkında yapilan toplam 615 yorum örneklemi oluşturmaktadır. Veriler, Maxqda'ye aktarıldıktan sonra tümevarımsal tematik içerik analizi yolu ile incelenmiştir. Veriler, "Durum”, “Uyum sağlayamayız, çünkü..." ve "Ne Yapmalı?" şeklinde üç ana başlık altında kümelendiğinde Suriyeli sığınmacıların, sosyal uyumu engelleyecek nitelikte ön yargılı, ayrımcı ve dışlayıcı bir söylemin öznesi olduğu görülmüştür. Sosyal uyum sürecini desteklemeyi amaçlayan çalışmaların öncelikle yerel toplumda ön yargılı ve dışlayıcı tutuma neden olan yanlış bilgilerin düzeltilmesini hedeflemesi gerektiği düşünülmektedir.

\section{Is it Possible to Live Together?:}

\section{Construction of the "Syrian Asylum Seeker" Discourse in Reader Comments}

\section{Abstract}

The issue of social cohesion has gained importance with the exhaustion of Syrian refugees' hopes for return and transition to Europe.The aim of the study is to evaluate social cohesion based on readers' comments on published news on web pages after approximately eight years of living together.The study is a descriptive qualitative study in phenomenological type. The research sample consisted of 615 comments on the news published between 01.05.2015 and 30.04.2019. After the data were transferred to Maxqda, they were examined by inductive thematic content analysis. When the data is clustered under three main headings as "Situation", "We cannot cohere, because..." and "What to Do?"; it is seen that Syrian asylum seekers are the subject of prejudiced, discriminatory and exclusionary discourse that prevents social cohesion.It is thought that the studies aiming to support the social cohesion process should aim at correcting the wrong information that causes prejudiced and exclusionary attitude in the local community.
Anahtar Kelimeler

Sosyal Uyum

Dijital Habercilik

Nefret Söylemi

Mülteciler

Makale Hakkında

Geliş Tarihi: 15.11.2019

Kabul Tarihi: 13.03.2020

Doi: 10.18026/cbayarsos.647227
Social cohesion

Digital journalism

About Article

Received: 15.11.2019

Accepted: 13.03.2020

Doi: 10.18026/cbayarsos.647227

Keywords

Hate speech

Refugees 


\section{Giriş}

Suriye'de 2011 yılının Mart ayında başlayan ve uluslararası güçlerin de müdahil olduğu iç savaş ile birlikte milyonlarca insan yerinden edilmiş ve birçoğu ülkesinden ayrılmak zorunda kalmıştır. Bölge, devam eden çatışmalar nedeni ile istikrarsızlığını korumaktadır. Tahmini rakamlara göre bu süreçte 511 bin Suriye vatandaşı doğrudan savaş nedeniyle veya yiyecek, ilaç gibi temel insani ihtiyaçlara erişemediği için ölmüştür(Human Rights Watch, 2018). Ülkelerinde başlayan iç savaşın ardından güvenli bir yaşama kavuşma umudu ile milyonlarca Suriyeli de coğrafi konumu nedeni ile önemli göç yolları üzerinde bulunan Türkiye'ye sığınmıştır. Ani ortaya çıkan soruna acil çözüm bulma telaşı neticesinde uygulanan "açık kapı politikası" gereği üç buçuk milyonun üzerinde Suriye vatandaşı sınır kapılarından içeriye toplu olarak giriş yaparak ülkenin farklı bölgelerine yerleşmiştir.

Resmi devlet söyleminde "misafir" olarak tanımlanan, merhamet duyguları ile yaklaşılan sığınmacılara yönelik ilk müdahaleler, temel ihtiyaçların karşılanmasına odaklanan bir sosyal yardım anlayışının ürünüdür. Günümüzde Avrupa'ya gitme umudu tükenen (Karataş vd., 2018, s. 52) ülkelerindeki kaos ortamına da dönmek istemeyen Suriye vatandaşlarının Türkiye' de kalma eğilimi gösterdikleri, işletmeler kurdukları, taşınmaz mal sahibi oldukları ve dil öğrenerek eğitim sistemine entegre olmaya çalıştıkları görülmektedir (Erdoğan, 2014, s. 7; Erdoğan, Erdoğan, vd., 2017, s. 11). Bu bağlamda birlikte yaşam, sosyal uyum ve kültürlerarası iletişim süreci ile ilişkili sorun alanlarının tanımlanmasına yönelik ilginin arttığı görülmektedir. Araştırmalar Suriyeliler ile yerel toplum arasında birlikte yaşamayı engelleyen ve kalıcı çözümler üretmeyi güçleştiren dışlayıcı bir söylemin, ayrımcilı̆̆ın ve belirgin bir sosyal mesafenin olduğunu göstermektedir (Erdoğan, Erdoğan, vd., 2017, s. 63; Eren ve Tunç, 2018, s. 21; Şimşek, 2017, s. 20).Sosyal uyuma yönelik kurumsal ve akademik ilgi artmakta iken bu süreci zorlaştıran etkenlerin betimlenmesi daha önemli bir hale gelmektedir.Bu çalışma, kamusal alanın dijital boyutunda dolaşımda olan söylem aracılığıyla/üzerinden yerel toplum ile Suriyeli sığınmacıların an itibariyle birlikte ve uyum içinde yaşama olasılığını değerlendirmeyi ve engelleyen unsurları betimlemeyi amaçlamaktadır.

\section{Mülteci ve Sığınmacı}

Tarihsel süreçte savaşlar, doğal afetler, yoksulluk, kıtlık, siyasi gerekçeler gibi çok çeşitli sebeplerle göç eden insanlar, sıklıkla ulusal sınırlarının ötesine yönelir. Bu hareketlilik sonucunda göç edenler birçok sorun ile karşılaşırlar. Uluslararası düzeyde yaşanan mağduriyetlerin giderilmesini amaçlayan ilk anlaşmalar, 1950 yılına kadar sınırlı sayıda ülke tarafından imzalanmış ve dar alanda uygulanmıştır. İkinci Dünya Savaşı'nın ardından Birleşmiş Milletler Mülteciler Yüksek Komiserliği (BMMYK) kurulmuş, sonrasında 1954 yılında uluslararası alanda geçerli ilk yasal metin olan Mültecilerin Hukuki Statüsüne İlişkin Sözleşme (Cenevre Sözleşmesi) yürürlüğe girmiştir. Avrupa'dan göç eden İkinci Dünya Savaşı mağdurları için kullanılan "mülteci" statüsü, 1967'de New York'ta imzalanan Ek Protokol ile coğrafya ve zaman kısıtlaması kaldırılarak yeniden tanımlanmıştır. Ancak Türkiye Ek Protokolü imzalarken, jeopolitik gerekçeler ile yalnızca Avrupa'dan gelenleri“mülteci" olarak kabul edeceğini belirtmiştir.

Mülteci, haklı bir nedene dayanan baskı ve zulüm korkusu nedeni ile ülkesinde güven ve huzur içinde yaşayamayan, bu nedenle başka bir ülkeye sı̆̆ınma talebinde bulunan ve bu talebi kabul edilmiş kişiler için kullanılan yasal tanım ve statüdür. Vatandaşı olduğu ülkeyi 
yaşamı tehlikede olduğu için terk etmek zorunda kalan ve geri dönemeyen ve henüz mülteci statüsü almamış kişiler ise "sığınmacı" olarak tanımlanmaktadır. Yıllar içerisinde Türkiye, başta Irak, Afganistan ve Kuzey Afrika ülkelerinden olmak üzere birçok sığınma talebini kabul etmiştir (Yıldız ve Sert, 2017, s. 93-94). Ancak en büyük talep, 2011 yılında başlayan Suriye savaşından sonra yaşanmış ve uygulanan "açık kapı politikası" gereğince üç buçuk milyondan fazla Suriye vatandaşı Türkiye'ye sığınmıştır. Göç mevzuatı nedeniyle üçüncü bir ülkeye gidinceye kadar "geçici iltica" kapsamında değerlendirildikleri, mülteci statüsünden ve haklarından yararlanamadıkları için 2013 yılında 6458 sayılı Yabancılar ve Uluslararası Koruma Kanunu (YUK) ile "geçici koruma statüsü" tanımlanmıştır. Bugün Türkiye'deki Suriyeliler bu statünün sağladığı olanaklar içinde yaşamlarını sürdürmektedir.

Göç edenlerin bir bölgede yaşama süresi arttıkça, kalıcı olarak yerleşme arzularının da arttığ1 görülmektedir (De Jong, 2000; Duncan ve Newman, 1976; Kan, 1999; Landale ve Guest, 1985; Mchugh, 1984). Yapılan araştırmalara göre Suriye'ye dönmeyi istemeyen (Erdoğan, 2014, s. 7; Erdoğan, Erdoğan, vd., 2017, s. 11) ve iç güvenliği önceleyen göç politikaları nedeniyle Avrupa'ya da geçemeyen (Şimşek ve İçduygu, 2017, s. 6; Üstübici, 2017, s. 107) Suriye vatandaşlarının Türkiye' de yaşama eğilimleri artmaktadır (Erdoğan, 2017, s. 26; Erdoğan, Erdoğan, vd., 2017, s. 3; Erdoğan, Şener, vd., 2017, s. 109; Erdoğan ve Ünver, 2015, s. 72-73; Kap, 2014, s. 34). Dolayısıyla, yerel toplum ile Suriyeliler açısından sosyal uyum ve birlikte yaşam konuları gün geçtikçe daha fazla önem kazanmaktadır. Her ne kadar 2017 yılı sonrasında yapılan çalışmalar, Suriyelilerin Türkiye' de kalacaklarına inanıldığını gösterse de yerel toplumun Suriyelilerle birlikte yaşama arzusu duymadığını (Erdoğan, 2014; Gülyaşar, 2017, s. 702-703) aralarında kültürel ve sosyal mesafe olduğunu (Erdoğan, 2017, s. 26; Erdoğan, Erdoğan, vd., 2017, s. 50; Erdoğan, Şener, vd., 2017, s. 109) gösteren çalışmalar da yapilmıştır.

\section{Sosyal Uyum}

Sosyal uyum, doğası gereği karmaşık ve tanımlanması zor, yeterince açık olmayan ve sıklıkla hatalı kullanılan (European Commission, 2005, s. 6; Friedkin, 2004, s. 409; Guay, 2015, s. 7; IOM, 2017, s. 3) bir kavramdır. Temelde birlikte yaşama ve gruplararası iletişimle ilişkili, bütünleşme ve içerme politikalarıyla bağlantılı olarak ele alınmaktadır. Sosyal uyum en genel anlamıyla toplumun,sınıf, etnik grup, din, kültür gibi ayrışmalardan doğan tehditlere rağmen bir arada yaşamasını mümkün kılan niteliklerinden biridir (European Commission, 2005, s. 70). Göç süreçleriyle bağlantılı olarak tanımlandığında sosyal uyum, göçmenler ve yerel toplum arasında süregelen dinamik etkileşimin ürünüdür (Saggar vd., 2012, s. 18-22). Fielden'a göre uyum süreci, hukuki, ekonomik ve sosyokültürel açıdan değerlendirilmesi gereken üç temel boyut içermektedir. Bu boyutlar, göç edilen ülkede vatandaşlara tanınan yasal, kendisinin ve ailesinin yaşamını sürdürebilmesini sağlayacak ekonomik haklara sahip olma ve ayrıca sosyal dışlanma ve ayrımcılığa maruz kalmadan kültürlerarası iletişim ve bağ kurma olanağ şeklinde özetlenmektedir (Fielden, 2008, s. 1). Sosyokültürel açıdan sosyal uyumu kolaylaştıran etkenler ise diğer grup üyelerini içerme (inclusion), onlara güvenme, işbirliği yapmaya istekli olma ve geniş iletişim ağıdır. Diğer yandan gruplar arasında güvensizlik, tecrit ve düşmanlık yaratan irkçılık ve zenofobia sosyal uyumu güçleştirmektedir (Rudiger ve Spencer, 2003, s. 6; Saggar vd., 2012, s. 25).

Türkiye'deki Suriyeliler bağlamında yapılmış çalışmalar, Suriyelilerin yerel topluma uyumunu temel alarak kişilerarası ilişkilere ve ağırlıklı olarak Suriyelilerin Türkçe öğrenmesine odaklanmaktadır (AFAD, 2014; Göç İdaresi Genel Müdürlüğü, 2017; Khalaf ve 
Ilgar, 2017; Süleymanov, 2017). Bu çalışmalarda sosyal uyum kapsamında aidiyet hissi, kendini güvende hissetme, toplumsal gerilimler, dışlanma ve ayrımcılık konuları işlenmektedir (Erdoğan, 2014, 2017; Erdoğan, Erdoğan, vd., 2017; Erdoğan, Şener, vd., 2017; Süleymanov, 2017; Yıldırımalp vd, 2017).

\section{Dijital Haber Okurları}

Günümüzde enformasyonun küresel ölçekte hızlı biçimde dolaşmasını mümkün kılan yeni iletişim teknolojileri sayesinde gazetecilik, dijital bir mecrada yeni olanaklara kavuşmuştur. Kuruluş, üretim ve dağıtım sürecinin birçok aşamasında yüksek maliyetlere katlanmayı gerektiren gazete, radyo, televizyon gibi geleneksel medyanın yerine dijital ortamda yayıncılık yapmayı mümkün kılan web tabanlı interaktif gazetecilik araçları yaygınlık kazanmıştır. Günümüzde temelleri geleneksel habercilik ilkelerine dayanıyor olsa da dijital mecrada sürdürülen habercilik, okurlara daha fazla seçim yapma ve haber üretim sürecine katkıda bulunma şansı vermektedir. Denilebilir ki, enformasyonun üretim ve dağıtım sürecindeki denetim, medya sahiplerinin ellerinden -kısmen- okurların eline doğru kaymıştır. Okurun ilgili haberleri, fotoğrafları, videoları vb. gruplandırarak, birbirlerine bağlayarak, heterojen bir yapılanma içindeki enformasyona ulaşmasını ve üretim sürecine katılmasını sağlayan rizomatik (Deleuze ve Guattari, 1990) bir yapı oluşmuştur. Dijital alanın sunduğu olanaklar sayesinde okurlar, egemen, müzakereci ya da muhalif (Hall, 2001) yorumları ile haberin anlamlandırılması sürecine kamusal alanda katkıda bulunur hale gelmiştir. Okur yorumları, habere ilişkin konuda dolaşımda olan söylemi görünür kılması açısından elverişli bir analiz yüzeyi oluşturmaktadır. Geleneksel habercilik kurallarından ve sınırlarından bağımsız olarak görüşlerini paylaşma olanağı bulan okurlar, haberin içeriği ile örtüşmeyen farklı okuma biçimleri, zaman zaman hakarete varan üslupları ile gündelik yaşamda dolaşımda olan söylemi aktarmaktadırlar. Hatta okurlar, aşina oldukları egemen söylemi yansitmayan haberleri muhalif yorumları ile tamamlayabilmektedir (Dursun, 2012, 11-12).Bu nedenle okur yorumları, sosyal uyumun önünde engel teşkil eden ve özneler aracılığıyla metinlerarası düzlemde inşa edilen söylemin deşifre edilmesi amaciyla kullanılabilir.Bu çalışmada da sosyokültürel açıdan uyumu zorlaştıran, iletişim ve bağ kurma olasılıklarını azaltan ön yargılı ayrımcı söylemin doğasının, temel sav ve stratejilerinin betimlenmesi amaçlanmaktadır.

\section{Yöntem}

\section{Araştırma Modeli}

$\mathrm{Bu}$ araştırma, fenomenolojik tipte betimleme amaçlı niteliksel bir çalışmadır. Araştırmanın temel amacı, Suriyeli sığınmacılar ile yerel toplum arasındaki sosyal uyumu destekleyenya da engelleyen ve haber okuyucularının yorumlarında sergilenen söylemi betimlemektir. Araştırmada yanıt aranan sorular şunlardır:

a. Suriyeliler ile birlikte yaşamak konusunda okurların genel eğilimi nedir?

b. Sosyal uyumu engelleyen ya da kolaylaştıran, Suriyelileri "Öteki" olarak inşa eden söylemin temel savları nelerdir?

c. Haber okuyucularının yorumlarına dayanılarak sosyal uyumu kolaylaştıracak hangi önerilerde bulunulabilir? 


\section{Evren ve Örneklem}

Araştırmanın örneklemi, Habertürk Gazetesi'nin web sayfasında yayınlanan haberler arasından seçilmiştir. Gazetenin seçilme nedeni, veri toplama sürecinin başladığı 2019 Mayıs ayı itibariyle Interactive Advertising Bureau (IAB) ölçüm sonuçlarına göre "gerçek kullanıcı sayısı" açısından ilk sıralarda yer alması ve okuyucularının yorum yapmasına izin vermesidir. Amaca uygun örnekleme tekniği ile belirlenen örneklem, 01.05.2015-30.04.2019 tarih aralığında Habertürk'te yayınlanmış 7 haber ve altındaki 615 okuyucu yorumundan oluşmaktadır (Tablo I).

Tablo 1. Araştırmanın Örneklemi

\begin{tabular}{|c|c|c|c|c|c|c|}
\hline $\begin{array}{l}\text { Haberin } \\
\text { Kodu }\end{array}$ & Haberin Başlığ1 & $\begin{array}{l}\text { Yayınlandığı } \\
\text { Bölüim }\end{array}$ & $\begin{array}{c}\text { Yayınlandiğı } \\
\text { Tarih }\end{array}$ & $\begin{array}{c}\text { Kelime } \\
\text { Sayısı }\end{array}$ & $\begin{array}{l}\text { Yapılan } \\
\text { Yorum } \\
\text { Sayıs1 }\end{array}$ & Yüzde \\
\hline $\mathrm{H} 1$ & $\begin{array}{c}\text { Ankara'da Türk } \\
\text { vatandaşlar ile Suriyeli } \\
\text { mülteciler arasında } \\
\text { kavga! }\end{array}$ & Gündem & 03.07.2017 & 239 & 76 & 12.4 \\
\hline $\mathrm{H} 2$ & $\begin{array}{c}\text { Cebinde } 80 \text { lirayla } \\
\text { Türkiye'ye kaçan } \\
\text { Suriyeli Haddad'ın } \\
\text { başarısı }\end{array}$ & Ekonomi & 30.10 .2017 & 397 & 91 & 14.8 \\
\hline $\mathrm{H} 3$ & $\begin{array}{l}\text { Sakarya'da Suriyeli } \\
\text { anneyi ve bebeğini } \\
\text { öldürenler hâkim } \\
\text { karşısında }\end{array}$ & Gündem & 01.12 .2017 & 1402 & 49 & 8 \\
\hline $\mathrm{H} 4$ & $\begin{array}{l}\text { Sağlık sektöründe } \\
\text { "Suriyeli Doktor" } \\
\text { dönemi }\end{array}$ & Gündem & 20.12.2017 & 151 & 147 & 23.9 \\
\hline H5 & $\begin{array}{c}\text { Suriyeli çocuk anne } \\
\text { konuştu: Bir daha } \\
\text { doğum yapmak } \\
\text { istemiyorum }\end{array}$ & Ropörtaj & 21.01.2018 & 507 & 43 & 7 \\
\hline H6 & $\begin{array}{l}\text { Kızılay Başkanı Kerem } \\
\text { Kınık: Suriyelilerin } \\
\text { yarısı dönmez }\end{array}$ & Ropörtaj & 04.03 .2018 & 1759 & 162 & 26.3 \\
\hline $\mathrm{H} 7$ & $\begin{array}{c}\text { Son dakika! Gaziantep'te } \\
\text { cinsel istismar iddiası } \\
\text { mahalleliyi sokağa } \\
\text { döktü }\end{array}$ & Gündem & 06.07.2018 & 497 & 47 & 7.6 \\
\hline Toplam & & & & 4952 & 615 & 100 \\
\hline
\end{tabular}

\section{Veri Toplama Süreci}

Google Arama Motoru'nun Haberler sekmesinde tarih aralığ "sığınmacı", "mülteci" ve "Habertürk" anahtar kelimeleri birlikte kullanılarak tarama yapılmıştır. Ulaşılan 301 haber içinde 20'nin üzerinde okur yorumuna sahip olan toplam 21 haber seçilmiş ve konuları itibariyle 7 ana temaya ayrılmıştır. Her bir temayı en iyi temsil eden ve aynı zamanda en çok okuyucu yorumuna sahip 7 haberin altındaki okur yorumları ayrı birer Word dosyasına kaydedildikten sonra Maxqda Programı'na aktarılmıştır. 


\section{Verilerin Analizi}

Araştırmada tematik kodlama ve sinıflandırmalar yolu ile düşünceleri betimlemeyi amaçlayan (Neuman, 2009, 381-384) tümevarımsal tematik analiz tekniği kullanılmıştır. İlk kodlamada, haberlerin altına yapılan yorumlardan elde edilen başlıklar kullanılmış, daha sonra kümeleme işlemine devam edilerek ana temalara ulaşılmıştır. Temalar, araştırmanın amacı doğrultusunda ve alanyazının edinilen kuramsal bilgiler ışığında yorumlanmıştır.

\section{Geçerlik ve Güvenilirlik}

Niteliksel araştırmalar "gerçek"e ilişkin "doğru" bilginin, özneler ve metinlerarası inşa edilen kesinlikten uzak bir kurgu olduğu fikrine dayandığı için niceliksel araştırmaların geçerlik ve güvenilirlik ile ilgili kaygılarının birçoğunu taşımaz. Bu tip araştırmalar doğası gereği değer-bağımlıdır (Kuş, 2007) ve genelleme amacı taşımaz. Veri toplama ve işleme sürecinin detaylı biçimde açılanması, çeşitleme (triangulation) yapılması ve araştırmacıları çalışmaya yönlendiren etkenlerin belirtilmesi araştırmayı geçerlilik ve güvenirlik açısından dikkate değer kılar(Dey 2003). Bu bağlamda, örneklemi oluşturan okuyucu yorumlarını içeren 21 haber, araştırmacılar dışında alandan bir uzmanın daha görüşü alınarak belirlenmiştir. Veriler araştırmacılar tarafından birbirlerinden bağımsız olarak ilgi ve ilişki düzeyine göre ayrı kategoriler halinde kümelenmiş, daha sonra birlikte çalışılarak uzlaşma yolu ile tümevarılmıştır. Son aşamada elde edilen ana temalar, altlarına yerleştirilen örnek yorumlar ile birlikte alanda çalışan farklı iki uzmanın daha değerlendirmesine sunulmuştur. Uyum düzeyi \%89olarak bulunmuştur.

\section{Araştırmanın Sınırlılıkları ve Güçlü Yanları}

Araştırma bulguları, amaçlı örnekleme tekniği ile seçilen haberlere yapılan yorumlar ile sinırlıdır. Haberlere konu olan olay/olgular hakkında paylaşılan görüşlerin, kişilerin gerçek tutum ve düşüncelerini, aynı zamanda sosyal uyum konusunda dolaşımda olan söylemi yansıttığı varsayılmaktadır. Araştırmanın güçlü yanı ise yürütücülerin iletişim ve sosyal hizmet olmak üzere iki farklı disiplinde çalışıyor olmasıdır.

\section{Bulgular}

Veriler, araştırma amacına uygun ve araştırma sorularını cevaplayacak biçimde incelendiğinde Şekil 1'de görüldüğü şekilde, 3 temel ve 9 alt tema altında kümelendiği görülmüştür.

\begin{tabular}{|c|c|c|}
\hline \multicolumn{3}{|l|}{ 1. DURUM } \\
\hline 1.1. Savaş bitti ama & \multicolumn{2}{|c|}{ 2. UYUM SAĞLAYAMAYIZ, ÇÜNKÜ... } \\
\hline gitmiyorlar & 2.1. Farklıyız & 3. NE YAPMALI? \\
\hline $\begin{array}{l}\text { 1.2. Misafırden bıktık } \\
\text { 1.3. İmtiyazlılar } \\
\text { 1.4. Ekonomik yük } \\
\text { 1.5. Çoğalıyorlar }\end{array}$ & $\begin{array}{l}\text { 2.2. Tehdit: Bunlar iyi } \\
\text { günlerimiz }\end{array}$ & $\begin{array}{l}\text { 3.1. Birlikte yaşayamayız. } \\
\text { Gitsinler! } \\
\text { 3.2. Birlikte yaşayabiliriz. } \\
\text { Kalsınlar! }\end{array}$ \\
\hline
\end{tabular}

Şekil 1. Temalar 


\subsection{Savaş Bitti Ama Gitmeyi Düşünmüyorlar}

Türkiye geçmişten günümüze uluslararası göç sürecinde hedef ülke olmaktan ziyade, kaynak ve geçiş ülkesi olarak rol oynamıştır; ancak Suriye Savaşı'nın dinamikleri daha önce yaşanan göç süreçlerinden farklıdır. Öncelikle, bu süreçte Türkiye'ye daha önce yaşanmamış ölçekte büyük nüfus girişi olmuştur. Türkiye'ye gelen Suriye vatandaşlarının bir kısmı Avrupa'ya geçmeyi, bir kısmı Türkiye'ye yerleşmeyi planlarken, diğer bölümü ise savaş bittikten sonra ülkelerine dönme ümidi ile geçici çözümler bulma umuduyla hareket etmiştir. Avrupa Birliği'ne üye ülkelerin sürdürdükleri göç politikası, geri gönderme sürecinin başlaması ve göçmen karşıtı politikaların yükselmesi ile birlikte Suriyelilerin Avrupa'ya geçme eğilimi oldukça azalmıştır. Diğer taraftan Suriye'de süren savaşın kısa sürede biteceğine duyulan inançve geri dönmeumutlarıda azalmıştır. Sonuç olarak, üç buçuk milyonun üzerinde Suriye vatandaşı -istemeseler bile- Türkiye'de yaşamını sürdürmek durumunda kalmıştır.

Yerel toplumun Suriye'den Türkiye'ye doğru 2011 yılında başlayan göç hareketine ilişkin gün geçtikte artan oranda dışlayıcı ve sert bir tutum sergilediği söylenebilir (Erdoğan, 2014; Gülyaşar, 2017, s. 702-703; Kardeş vd., 2017, s. 197). Bu çalışmada da Suriyeli sığınmacılarla ilgili web üzerinde yayınlanan haberlerin altına yapılan 615 yorumun çoğunluğunda (\% 86) genel bir memnuniyetsiz duygusunun hakim olduğu görülmektedir.

"Ben Türkiye'den bıktım önüne geleni alıyorlar, artık yaşanmaz hale geldi Türkiye"(H6)

"Yakında tek ve en büyük sorunumuz bunlar olacak" (H7)

"Yazıklar olsun, ülkemizi ne hale getirdiler"(H1)

Suriye'deki çatışmalar ve ülke içinde süregelen karışıklık, örneklemin seçildiği ve makalenin yazıldığı 2019 yılı itibariyle halen devam etmekte ve ne zaman sona ereceği konusu halen belirsizliğini korumaktadır (Özalp, 2019). Türkiye'de yaşayan Suriye vatandaşlarının ülkelerine geri dönmesi sadece savaşın bitmesine değil, aynı zamanda ülkede temel yaşam ihtiyaçlarını karşılayabilecekleri şartların oluşmasına da bağlıdır. Oysa ki çatışmanın olmadığı ya da geçici sürelerle kesildiği bölgelerde dahi konut, gıda, elektrik ve temiz su kaynakları gibi en temel insani gereksinimler (Maslow, 1943; Max-Neef, 1992) karşılanamamaktadır. Bu koşullar altında uzun süredir bir arada yaşayan iki toplum hakkında sosyal uyumu kolaylaştıran unsurların söyleme egemen olması beklenir (Çuhadar Gürkaynak, 2012, s. 255; Hewstone ve Swart, 2011, s. 375); ancak haberlere yapılan yorumlar incelendiğinde okurların savaşın ve çatışmaların bittiği ve sığınmacıların ülkelerine dönmeleri gerektiği kanaatinde oldukları görülmektedir.

"Savaş bitti, İdlib'de doktor ihtiyacı var, Türk doktorlar gidiyor"(H4)

"Suriyelileri istemiyoruz. Savaş bitti. Geri gönderin."(H3)

$\mathrm{Bu}$ yorumların yazılmasında en önemli etken Suriyelilerin bayram nedeni ile ülkelerine döndükleri hakkındaki haberlerdir. Sığınmacıların Suriye'ye dönebilmesini savaşın bittiğinin, Türkiye' de refah içinde yaşadıklarının kanıtı olarak değerlendirmişlerdir. Örneğin Habertürk'ün 04.03.2018 tarihli ve H6 kodlu haberinin altına yapılan yorumda, "ben memlekete zor gidiyorum izinlerde. Adamlar elini kolunu sallayarak ülkeye giriyor. Lükse bak" şeklinde durumun yarattığı rahatsızlık dile getirilmiştir. Benzer şekilde H4 kodlu habere yapılan yorumda da "Gönderin şunları. Madem savaş var, niye bayramlaşmaya gidiyorlar?" ifadeleri kullanılmıştır. 
Yorumlarda, Suriyelilerin Türkiye'de oldukça rahat yaşadıkları, bu nedenle savaş bittiği halde ülkelerine dönmek istemedikleri farklı savlarla ilişkili olarak sıkça dile getirilmiştir. Örneğin 30 Ekim tarihli ve H2 kodlu Suriyeli bir iş insanının başarısına ilişkin haber, "adam sahiplenmiş, bir de bizim kendimizi Araplara tantmamız gerekiyor, diyor vay be" şeklinde eleştirilmiştir. Sosyal uyum ve kaynaşmanın göstergesi olarak yorumlanabilecek bu önemli olay haber okurları tarafından, sığınmacıların ülkelerine geri dönmeyeceklerinin, Türkiye'yi ele geçirme arzusu duyduklarının göstergesi olarak algılanmış ve kaygı ile karşılanmıştır. H2 kodlu habere yapılan "Ülkeyi artık benimsemiş ya ne Arap'ı! Böyle böyle yarın öbür gün iyice üredikten sonra Akdeniz'i, Ege'yi, Karadeniz'i ya da Marmara'yı da bunlar ister artık." yorumuna benzer şekilde, Karataş'ın 2015 yılında yaptığ çalışmada da yerel toplumun Suriyeli sayısını artmasından endişe duyduğu tespit edilmiştir (Karataş, 2015, s. 136).

Okurların bir kısmı yorumlarında Suriye'de eğitimli insan gücüne olan ihtiyacı ön plana çıkararak sı̆̆ınmacıları ülkelerinin yeniden inşa sürecine katılmak istemeyen, vatanını sevmeyen "korkak" insanlar olarak nitelemiştir. Özellikle Sağlık Bakanlığı'na bağlı hastanelerde görevlendirilmesi planlanan Suriye vatandaşı doktorlarla ilgili H4 kodlu haber ile Gaziantep'teki cinsel istismar iddiasına ilişkin H7 kodlu haberin altında yapılan yorumlar bu imaları içermektedir.Kullanılan üsluba dayanılarak sosyal uyum sürecinde aşılması gereken engellerin büyük olduğu rahatlıkla söylenebilir.

"Esad çağırdı geriye vatandaşlarını, gitmiyorlar."(H7)

"Gidip kendi ülkelerindeki insanlara hizmet etsinler. Onlarn daha çok ihtiyacı var doktora. Mesleği ne olursa olsun, gerekçesi ne olursa olsun, onlar korkak. Hiçbir ülkeye faydaları olmaz. Onların artık vatanı yok."(H4)

"Sen adamların öğretmenini doktorunu mühendisini alırsan kim inşa edecek Suriye'yi? Kim hizmet edecek oralarda?"(H4)

Kamusal alanda Suriyelilerin topluma uyum sağladığını ve refah seviyesinin yükseldiğini gösteren olaylar, okurlar tarafından artık muhtaç olmadıklarının ve ülkelerine geri dönmeleri gerektiğinin işareti olarak değerlendirilmiştir. Nargile içmeleri, vanDijk'ın eleştirel söylem stratejilerinden "kanıt gösterme" yoluyla Türkiye'de rahat yaşadıklarının göstergesi olarak kullanılmıştır (VanDijk, 2000). Örneğin, "yaz geliyor simdi nargile keyfi yapacaklar, ellemeyin!" (H6); "Kızılay nargile dağıtsın! En önemli ihtiyaç Suriyeli kardeşlerimiz için..." (H6); "Suriyeli Gençler nargile içip keyif yaparken, aynı yaşlardaki bizim evlatlarımız Suriye'de savaşıyor. Sorun burada" (H6) gibi...

Okurlar/izleyiciler yakın çevrelerinin özellikle ülke sınırlarının dışında kalan gündemi sadece medya aracılığıyla takip edebilir. Bu nedenle Suriye'de yaşanabilir bir ortam oluştuğuna ilişkin yanlış kanaatin medyanın izlediği yayın politikasının sonucu olduğu, "savaşın bittiği" savına dayanan bu yorumların Suriye ile ilgili tek ve temel haber alma kaynağı olan medyadaki haberlerden kaynaklandığı düşünülebilir.

\section{2. "Misafirden bıktık"}

Suriyeli sığınmacılara yönelik olumsuz tutumun bir diğer nedeni, sürecin başlangıcından itibaren Türkiye'ye gelen Suriyelilerin resmi söylemde "misafir" olarak nitelenmesidir. "Misafir" veya "konuk” Türk Dil Kurumu'nun Güncel Türkçe Sözlüğü’nde “bir yere veya birinin evine kısa bir süre kalmak için gelen kimse" şeklinde tanımlanmıştır; yani siyasilerin konuşmaları ile söyleme yerleşen kelime doğası gereği Suriyelilerin geçici olarak Türkiye' de konakladıklarını ifade etmektedir. Bu söylemsel kuruluş nedeni ile ev sahibi yerel toplum, Suriye vatandaşlarının Türkiye'de kaldıkları sürenin uzamasını, her türlü ayrımcı söylemin 
ana gerekçesi olarak kullanmıştır. H6 kodlu habere yapılan bir yorumda sınır kapılarında içeriye "misafir" olarak girdikleri ve ülkelerinde savaş bittiği halde geri dönmedikleri, ev sahibinin "güvenin(i) suistimal ettikleri" dolayısıyla "bu işin hayırdan çıktığı" yazılmıştır. Suriyelilerin ülkenin farklı bölgelerine yayılmasının ülkeyi yaşanmaz hale getirdiği, Suriyelileri ağırlamanın "artık bir hayır işi olmadığı" söylenmiştir (H1).

Aynı yaşam ortamını sürekli paylaşmak zorunda oldukları fikri, hiçbir okur yorumunda görülmediği gibi ortak arzu Suriyelilerin artık gitmesi gerektiğidir. Bu konuda sarfedilen kelimeler "her yerdeler"(H1), "ülkeyi sahiplenmişler (H2)", "ortak olmaya devam edin ülkeye" (H2), "yayım yayım yayıldıktan sonra bekleriz ki gidersiniz" (H2), "yeter artık" (H4), "bıktık" (H4), "bunlar çulunu serdi buraya" (H1) gibi sıralanabilir. Sosyal uyum çerçevesi içinde düşünüldüğünde bu üslubun yerel toplumun sığınmacilarla birlikte yaşamaktan duyduğu rahatsızlığın göstergesi olduğu söylenebilir. Örneklemde yer alan haberler, Suriyeli iş insanlarının başarılarından ya da sığınmacılar ile yerel toplum arasında kurulan bağlardan bahsetse bile altında yapılan yorumlar sosyal uyum konusunda aşılması gereken engellerin büyüklüğünü göstermektedir:

"Türkiye'de nereye baksak onlar var. Biz mülteci olduk vatanımızda!" (H1)

"Güzelim ülkemde yabancı olduk resmen. Metroda Türk göremez olduk, plajlardan bahsetmiyorum. Artık biri bunlara dur desin." (H1)

"Sessiz sedasız yerleşiyorlar, yemekteyiz programında gördüm bir tanesini."(H4)

"Yakında Suriyeli futbolcuda alırı milli takıma. Suriyeli avukat, hâkim, savcı, mühendis... Neyse biz gidelim buradan."(H4)

Bu bağlamda Ankara'da yaşanan ve Suriyeliler ile yerel toplumun karşı karşıya geldiği olaylara ilişkin H1 kodlu habere yapılan yorumlar önemlidir. Yorumlarda Suriyelilerin "sorun çıaran", "nankör", "ev sahiplerinin değerini bilmeyen" ve "suçlu” olduğu iddia edilmekte, zorla gönderilmeleri gerektiği ileri sürülmektedir.

"Artık bunların Türkiye'den sınır dışı edilmesi gerek. Bunlar nankörler. Besle kargayı oysun gözünü!

Türkiye'de Suriyeli istemiyoruz sayın cumhurbaşkanım. Deolet büyüklerimiz, millet bıktı artık bunlardan"(H1)

"Nankör aşağıllk varlıklar! Onların yüzünden ne dolmuşa ne otobüse binebiliyoruz, ne de yolda yürüyebiliyoruz."(H1)

"Yeter artık bu Suriyelilerden çektiğimiz! Burası bizim ülkemiz!" (H1)

Haber dili olayı çerçevelerken -görece- tarafsız bir tutum sergilemeye çalışsa bile, okurların muhalif okuma yaparak, medyayı olayın ciddiyetini ve önemini azaltmaya çalışmaklasuçladıkları görülmektedir. Örneğin;

"Küçük çaph dedikleri olaya hem Ankara Valisi hem de Ankara Emniyet Müdürü geliyor! Bütün Demetevler ayaktaydr sabaha kadar"(H1)

\subsection{Imtiyazlılar}

Okurlar, haberlerin altına yaptıkları yorumlarda Suriyeliler ile "artık birlikte yaşamak istemediklerini", çünkü onlara kendilerine tanınmayan "imtiyazlar" verildiğini ileri sürmüştür. Mülteci Hukuku'ndan doğan hakları olmasına rağmen okurlar, sığınmacılara yapılan sosyal yardımların, sağlık hizmetinden ücretsiz yararlanabilmelerinin, çalışma izni almalarının "ayrıcalık" olduğunu düşünmektedir. Bu düşüncenin kökeninde neoliberal ekonomi politikalarının ürünü olan sosyal devletin küçültülmesi gerektiği inanışı olabilir (Özdemir, 2007, s. 137-139). Sosyal adaletin sağlanması, toplumda sosyal refahın arttırılması açısından sosyal yardımlar şüphesiz önemli ve yararlı araçlardır. Ancak söz konusu Suriyeli 
sığınmacılar olduğunda sosyal yardımın bir hak olarak değil, bir ayrıcalık ya da lütuf olarak kavrandığ1 anlaşılmaktadır. Ülke vatandaşlarına sağlanmadığı düşünülen olanakların "misafirler"e verilmesi, "Suriyeli kadar kıymetimiz yok!" (H6) şeklinde dile gelen olumsuz tutumun meşrulaştırılması için kullanılmıştır. H6 kodlu habere yapılan yorumlardan birinde "Bir aylık maaşını alma desek bırakmaz. Babasının parası sanki!" ifadesiyle katılımc1, bu durumu örneklemektedir. Bu temada kümelenen savlar, Suriyeli iş insanının başarısına ilişkin haber (H2) ile Kızılay Başkanı ile yapılan röportajın(H6) altında yoğunlaşmıştır.

\section{"Bunlara tanınan imtiyazı bizimkilere tanısaydılar şu an Türkiye'de Silikon Vadisi bile kurulurdu." (H2) \\ "Kendi milletinizden ne kadar vergi, zam alsak diye yırtınıyorsunuz; Suriyelilere gelince yardım, para desteği, iş imkânı, özel imkânlar, onlar bizim kardeşimiz... Peki, biz neyiz?" (H6) \\ "...Aylık 1500 TL bedava para, 250 kira yardıml, bedava ekmek, bedava sağllk hizmetleri kim gitmek ister?" (H4)}

Kızılay Başkanı ile yapılan röportajın altında yapılan yorumlarda, okuyucuların tepkisi sığınmacılara yapılan sosyal yardımlar üzerinde yoğunlaştığı görülmektedir. Metin içerisinde $\mathrm{AB}$ fonlarından karşılandığı belirtilmesine rağmen okurlar yardımların vergilerden ödendiğine ilişkin inancı (topoi) birçok yorumda yinelemiş, sert ve zaman zaman nefret söylemine varan bir üslup kullanmışlardır.

"Cumhurbaşkanı 30 milyar Euro harcadık diyor. Suriyelilere Avrupa söz verdiği 3 milyar Euro'yu ödemedi diyor. Demek ki senin-benim cebinden ödeniyor. Hem de fazlası, o para ile ülke kurulur" (H6).

"Birader, AB'nin verdiği rakam sinırl birader... Bitince Türkiye tamamlayacak birader. 30 milyar dolarcık harcadık. Türkiye Suriyeli üniversite öğrencilerine de ödeme yapıyor birader"(H6).

"Türkiye vatandaşından alın, başka ülkenin vatandaşına dağıtın. Benim hakkım haram olsun! Bana sormadan benim paramı dağıtıyorsunuz"(H6).

Suriyelilerin "imtiyazlı oldukları"nı kanıtlamak için ileri sürülen savlardan birisi de "vergiden muaf oldukları"dır. Örneğin H2 kodlu habere yapılan yorumlar "vergide vermiş mi acaba, yoksa vergi muafiyetinden mi faydalanmış? Bu ülkenin benden aldığ vergi cebimde kalsa güllük gülistanlık geçinip giderim" ve "Suriyeliler için çiftlik bu ülke. İsyeri açma ruhsatı yok, vergi yok, askerlik yok, yok da yok!" şeklindedir. Suriye vatandaşları da Türkiye vatandaşları gibi açtıkları her türlü işletme için vergi ödemek zorundadırlar; ancak siyasetçilerin medyada da yer bulan birçok demecinde dile getirildiği gibi denetimlerin yetersiz olması nedeni ile vergi ödemeksizin kayıtdışı çalışabilmekte ve oluşan haksız rekabet ortamı yüzünden yerel işletmeler kapanabilmektedir (Esnafı bitiren ayrıcalık, 2014;Kızılkaya, 2014).

Sığınmacıların düşük ücret ile istihdam edilmesi, yerel toplumda aynı işlere talip olan sosyoekonomik düzeydeki kesim açısından ciddi sorun yaratmakta ve Suriyelileri yeren karşıt söylemi güçlendirmektedir. Bilindiği gibi Türkiye'de kayıtdışı ekonominin büyüklüğü yeni bir sorun alanı değildir; iş sağlığı ve güvenliği açısından riskli ve sosyal güvencesi olmayan düşük ücretli işlerde çalışmak zorunda kalan birçok işçi bulunmaktadır (Buz ve Aygüler, 2017, s. 184; Öztürk ve Çetin, 2009, s. 2676; Sapancall, 2008, s. 8). İncelenen yorumlarda sığınmacılar, maalesef mağduru oldukları emek sömürüsünün nedeni olarak çerçevelenmiş, "vergi vermeyen, kayıt dışı 'çalışkan göçmen' "(H2); "kaçak çalışmanın adı esnek istihdam olmuş. Peki, yasal çalışanın maaşından kesilen vergiler?"(H6) şeklinde işverenin vergi ödememesinin de sorumlusu ilan edilmiştir.

Suriyelilerin sağlık hizmetlerinden ücretsiz yararlanabilmesi de nefret söylemini besleyen unsurlardan biridir. Örneğin, 
"Sağhlk beleş her şey beleş! Burası babalarmın ülkesi zaten değil mi? Biz de eczaneden ilaç alırken, borcu ödemeden ilaç alamayalım" (H6)

"Bedava sağlık hizmeti! Kendi vatandaşının en fakirinden bile 54 TL genel sağllk sigortası parası alıyorsun ama!" (H6)

Suriye vatandaşı olan hekimlerin geçici koruma altındaki bireylere hizmet vermek üzere Türkiye'de çalışabilmesi için 1 Nisan 2017 tarihinde Yabancı Sağlık Meslek Mensuplarının Türkiye'de Özel Sağlık Kuruluşlarında Çalışma Usul ve Esaslarına Dair Yönetmelikte Değişiklik Yapılmasına Dair Yönetmelik çıkarılmıştır. Suriyeli hekimlere Türkiye' de çalışma izni verildiğine ilişkin haberin (H4) altına hekimlerin diplomalarının sahte olduğu, yeterli eğitim almadıkları, sınava girmedikleri için mesleki açıdan yeterli olup olmadıklarının bilinmediği, ülke standartlarının altında oldukları gibi suçlayıcı ifadelerle hak etmedikleri bir ayrıcalığa sahip kılındıkları ileri sürülmüştür. Türkiye'de Tıp Fakültesi'ni bitiren hekimlere haksızlık yapıldığı inancı dile getirilmiştir.

"Ne güzel ülke oh ne ala bizler branş alabilmek için çırpınalım. Adamlar sertifikayla nasıl ve ne şekilde bitirdiğgi belli olmayan branşlarla hekimler ordusuna dâhil edilsin. Oh be, ne kadar güzel! "(H4).

"Yurt dışından mezun olan ve 'denklik' verilmeyen doktor gençlerimizin durumu ne olacak? 1500 T.C. vatandaşı doktor denklik bekliyor" (H4).

"Bulgaristan göçmeni bir doktordan denklik isteniyorken burada niye ISTENMIYYOR? Suriye'deki eğitimin kaliteli olduğunu nerden biliyorsunuz!"(H4)

Türkiye'deki üniversitelerde belirlenen kontenjanlar dahilinde eğitim alabilmek için tüm yabancı uyruklular sinava (YUS) girmek zorundadırlar. Yabancı uyruklu öğrenci kontenjanları sınırsız ve özel üniversiteler ücretsiz değildir ancak okur yorumlarında Suriyelilerin üniversite eğitiminden yararlanmaları da bir ayrıcalık olarak nitelenmiştir.

Okurlar ayrıca sığınmacıların Suriye sınırından kolay girip çıtıklarına ve ülke içerisinde istedikleri ilde yaşamalarının mümkün olduğuna inanmaktadırlar. Sığınmacıların bir turist gibi keyif odaklı bir yaşam sürdüğü ileri sürülmüştür:

"Ben memlekete zor gidiyorum izinlerde. Adamlar elini kolunu sallayarak ülkeye giriyor. Lükse bak!"(H6)

"Bu Suriyeliler başımıza bela oldu. Çok rahat geziyorlar Sayın Cumhurbaşkanımız bu işe bir dur desin, göstersin o büyüklü̈̆̈̈п̈̈."(H1)

\subsection{Ekonomik Yük}

"Biz/Onlar" dikatomisinin en fazla yinelendiği temalardan biri Suriyelilerin ekonomik yük oldukları savıdır. Okuyucuların, Suriyelilere bütçeden kaynak aktarıldığına dair güçlü bir inanç beslediği görülmüştür. Örneğin,

"Vay Kizılay vay! ...kimin parasını kime veriyorsunuz sayın yetkililer?"(H6)

"Türkiye vatandaşından alın başka ülkenin vatandaşına dağıtın benim hakkım haram olsun bana sormadan benim paramı dağıtıyorsunuz."(H6)

"Verdikleri paralar bizim cebimizden çıkıyor. Et bile yiyemiyoruz."(H6)

"Verdiğimiz para yurtdışından geliyormuş. Ya yürü git! Bari yaptı̆̆ımız fedakârlı̆̆ı hiç etme. Ayıptır günahtır!"(H6)

Yüksek enflasyon, artan işsizlik, kişi başına düşen gelirin, hane halkı ve özel sektör satın alma gücünün azalması gibi göstergelerden yola çıkılarak "kırılgan" Türkiye ekonomisinin zor bir süreçten geçtiği söylenebilir (Cinel, 2019, s. 65); ancak okurların ekonomik sorunları, sığınmacıların ülkeye gelişi ile ilişkilendirdiği anlaşılmıştır. "Suriyeliler yüzünden ekonomi ve günlük hayat mahvoldu", "ülkemizde işsiz güçsüz insan doluyken... Suriyeliler sırtımızda bir yükten başka bir şey değil"(H7), "bizim ülkemiz de milletimiz de çok zengin değil. Biz bu kadar Suriyeliye 
nasıl bakalım?"(H1) ifadelerinden de anlaşılacağı gibi okuyucular, sığınmacıları ülke ekonomisi üzerindeki "yük" olarak görmektedirler. Yorumlarda Türkiye'de eğitimli gençlerin emeklerinin boşa gittiği, işsizlik oranının arttığı, buna karşın "her yerde" Suriyeli işçi çalıştığ1 (H4) ileri sürülmüştür. Karataş' ın yaptığ1 çalışmada da benzer biçimde yerel toplumun iş gücü olanaklarının ellerinden alındığınainandığ tespit edilmiştir (2015, s. 137).

\section{5. Çoğalıyorlar}

Göç İdaresi Genel Müdürlüğü'nün 2019 yılı istatistiklerine bakıldığında 7.11.2019 tarihi itibariyle Türkiye'de geçici koruma statüsü altında 3.682.434 Suriyelinin yaşadığı, bu nüfusun \%45,8'ini kadınların oluşturduğu görülmektedir. Önemli bir bölümü Türkiye'ye geldikten sonra doğan 0-4 yaş aralığında toplam 572.544 kayıtlı çocuk bulunmaktadır (Göç İdaresi Genel Müdürlüğü, 2019). Suriyelilerin çok çocuk sahibi olmak istedikleri, aile planlaması yöntemlerini kullanmayı tercih etmedikleri yapılan bazı araştırmalarda belirlenmiştir (Karataş vd., 2018, s. 30-32). Bu durum, yorumlarda "ülkenin demografik yapısının bozulduğu"na (H6) ilişkin iddialar şeklinde sıkça dile getirilmiştir. Cümlelerde, "doğurmak" kelimesi yerine "hızla çoğalmak" (H6) ve "tavşan gibi üremek" (H1) ifadelerinin tercih edildiği ayrıca Türkiye Cumhuriyeti vatandaşı olmayı arzu ettikleri (H1) için bu durumun yerel tplum açısından tehdit oluşturduğu ima edilmiştir. "Çoğalan Suriyeliler" in ayrıcalık kazanacağına dair gerçekçi olmayan ancak endişe yaratan topki dile getirilmiştir.

2. "Uyum Sağlayamayız Çünkü..."

Suriyelilerin "istenmeyen misafirler" olarak görüldüğü haber yorumlarından yola çıkılarak okur yorumlarında sosyal uyum açısından "birlikte yaşamak mümkün mü?" sorusunun yanıtı aranmıştır. İleri sürülen savlar, sosyal uyumu güçleştiren ön yargıları ortaya çıkarmaktadır.

\subsection{Farklıyız}

Kimlik doğası gereği “Öteki” yani "Biz olmayan” üzerinden inşa edilir; başka bir ifade ile "Biz" ancak "Onlar" ile birlikte var olabilir. Bu bağlamda ön yarg1 ve ayrımcilığın temel nedenlerden biri kimliğin inşa sürecidir. Farklı olanlara atfedilen özellikler, bu süreçte yerel olan "Biz" $\mathrm{i}$ olumlamanın aracı haline gelir ve "Onlar"a ilişkin önyargılar ve stereotipler pekişir. Araştırma verileri incelendiğinde "Biz/Onlar Dikatomisi"nin (VanDijk, 2000) tüm yorumlara hakim olduğu görülmektedir. Durumu iyi örnekleyen yorumlardan birinde " $b u$ insanlarn kültürleri böyle, Türklerden farkllar. Millet ekmek derdindeyken bunlar ha bire çoğalıyor, gün bulup gün yaşıyorlar"(H1) denilmektedir. Bu kategorileştirmede Türkler "ekmek derdinde", sığınmacılar ise "keyif içinde ve çoğalmak için yaşayan insanlar" olarak nitelenmiştir. Uluslararası bir haber sitesinin sosyal medya sayfasında yayınlanan mültecilerle ilgili haberlerin altına yapılan yorumları inceleyen bir araştırma da bu durumu örnekler niteliktedir. Doğu-Batı, Müslüman-Hıristiyan, Gelişmiş-Az Gelişmiş ayrımının söz konusu yorumlarda sıkça kullanıldığı görülmüş, sonuç olarak araştırmada dijital nefret söyleminin kaynağında daha kompleks ve köklerini geçmişten alan ön yargıların bulunduğu belirtilmiştir (Kuş, 2016, s. 111). Göçmen karşıtı söylem bu nedenle bütün dünyada, siyasi söylemlerin ötesinde toplum nezdinde karşılık bulmakta ve popülist siyasetçiler tarafından yeniden üretilmektedir. Göçmenlerin bir bütün olarak refah bağımlısı, hastalık taşıyıcısı, toplumsal düzene karşı bir tehdit, potansiyel suçlu ve "Biz"den farklı olarak ötekileştirilmeleri, uluslararası terörizmin yarattığı tedirginlikle de birleştiğinde, toplumun çeşitli katmanlarında tehdit olarak algılanmalarına yol açabilmektedir (Rumelili ve Karadağ, 
2017, s. 70). Araştırma kapsamında incelenen yorumlarda kurgulanan ve tehdit algısını besleyen “Biz /Onlar Dikatomisi” Tablo 2'de özetlenmiştir.

Tablo 2. İdeolojik Kare (Biz/Onlar Dikatomisi)

\begin{tabular}{cc}
\hline Biz & Onlar \\
Türk & Arap \\
Türkiye Cumhuriyeti vatandaşı & Suriye vatandaşı \\
Ülkenin sahibi & Az gelişmiş ülke vatandaşı \\
Askerlik yapan & Misafir \\
Vatanı için savaşan & Asker kaçağı \\
Savaşçı & Vatan haini \\
Nitelikli & Korkak \\
Eğitimli & Niteliksiz \\
Çalışkan & Cahil \\
Asil & Tembel \\
& Pis \\
& Kanun tanımaz \\
Mağdur & Suçlu \\
& Arsız \\
& Hırsız \\
Kendi ülkesinde mülteci olan & Güvenilmez \\
Değeri bilinmeyen & Tehdit unsuru \\
Vergi veren & Kadın ve çocuklara sahip çımayan \\
Kamusunu koruyan & Irz düşmanı \\
Kadına saygı duyan & Tecavüzcü \\
& Tacizci \\
Yardım eden & Pedofili \\
& Mazlum gibi görünen ama mazlum olmayan \\
& Ayrıalıklı \\
\hline
\end{tabular}

\subsection{Farklıyı: Bunlar iyi günlerimiz}

Araştırma verilerinin tümü incelendiğinde yorumların çoğuna sığınmacıların neden olduğu ortak bir endişenin eşlik ettiği gözlenmiştir. Suriye'nin uzun yıllar ülke gündeminde terör ile birlikte anılması, sı̆̆ınmacıların toplu geçişleri sırasında yeterli kontrolün yapılamadığına ilişkin medyada yer bulan haberler (Suriye'de bombalı araç, 2019) Suriyeli sığınmacıların başta ulusal güvenlik olmak üzere birçok alanda tehdit olarak algılanmasının temel nedeni olarak düşünülebilir. Ancak tehdit algısı, Suriyeli sığınmacılara ilişkin önyargılardan da kaynaklanıyor olabilir; çünkü Rettberg ve Gajjala'nınçalışmasında da görüldüğü gibi Orta Doğulu erkekler, "potansiyel terörist" ya da "tecavüzcü" olarak görülebilmektedir (2016, s. 179). Kuş'un nefret söylemine ilişkin araştırmasında da Suriyeli sığınmacıların radikal gruplara atfedilen "terörist", "cihatçı" gibi kelimelerle birlikte anıldığ ve etiketlendiği belirtilmiştir (Kuş, 2016, s. 110). Sosyal medya kullanıcılarıyla yürütülen bir başka çalışmada da benzer biçimde sığınmacıların güvensizlik ortamı ve huzursuzluk yaratan bireyler olarak algılandıkları saptanmış, ayrıca bu düşüncelerin oluşmasında 
sığınmacılarla yaşanan deneyimler kadar medyada yer bulan haberlerin de etkili olduğu belirlenmiştir (Kardeş ve ark, s. 185). Bu araştırmada da yorumların çoğunda görülen tehdit algısının, ev sahibi olmanın getirdiği üstünlük duygusu ile birleşerek etnik köken, kültür, inanç ya da ekonomik temeldeki farklılıklara dayandırılan dijital bir nefret söylemini beslediği görülmüştür. Okurlar "bunlar daha iyi günler" (H7), "gidişat çok kötü"(H7), "başımıza belâ olacaklar istemiyoruzzzzz"(H1), "bunlar on yıl sonra başımıza bela olacaklar resmen Arap ülkesi olduk hayırlı olsun"(H4) gibi ifadeler kullanarak tehlikenin yaklaştığına ilişkin yorumlar yapmıştır. Yapılan araştırmalarda yerel toplumun Suriyelileri istememe sebepleri arasında, toplumun huzurunu bozdukları ve güvenliği tehdit ettikleri algısının önemli bir etken olduğu belirtilmektedir (Erdoğan, Şener, vd., 2017, s. 85; Kardeş vd., 2017, s. 197). Bu çalışmada da "bu adamlar suç işliyor; bu kadar çok insan ileride bu topraklarda kaos çıkarır; bu kadar haksızlık yeter!"(H6); "... azıcık gözünüzü açın artık. Suriyeliler tehlike ülkemiz için"(H1) ve "artık çocuklarımızı dışarı çıkaramıyoruz, ülkeyi bozdular"(H7) şeklinde tehdit algısını örnekleyen yorumlar yapıldığı görülmektedir. Yerel toplum ile sığınmacılar arasında yaşanan ve haberlerde bahsi geçen gerginlikler kanit olarak kullanılarak bu algı güçlendirilmiştir. Bilimsel araştırmalar göç sürecinde yerel toplum ile göç edenler arasında sorunlar, kavgalar, tartışmalar yaşanabileceğini ve hatta küçük gerginliklerin adli vakalara dönüşebileceğini göstermektedir (Karataş, 2015, s. 144). Bu durum, farklı kültürlerin karşı karşıya gelmesinden doğan sosyal uyum sürecinin bir parçası olarak değerlendirilmektedir. Söz konusu gerginlik anlarında göçmenler, benzer durumdakilerle ortak hareket ederek kendilerini savunma meyli sergilemektedirler. Araştırma kapsamında incelenen yorumlarda ise Suriyeliler ile yerel toplum arasında yaşanan toplumsal gerginliklerin, nefret söylemini pekiştirmek amacıyla kullanıldığı görülmüştür.

Suriye vatandaşlarının yerel toplum için tehdit oluşturma potansiyeli taşıdığı "çoğalma" teması ile de ilişkilendirilmiştir. "Ne gitmesi? 7 yılda hepsi üredi çocukları T.C. vatandaşı oldu" (H7) örneğinde de görüleceği gibi sığınmacıların TC vatandaşı olma olasılığı, kaygı yaratan unsurların başında gelmektedir. Yapılan araştırmalarda da yerel toplumun Suriyelilere vatandaşlık verilmesine sıcak bakmadığı belirlenmiştir (Erdoğan, 2014; Gülyaşar, 2017, s. 702-703). Bu kaygı özellikle 4 Mart tarihli ve H6 kodlu Kızılay Başkanı'yla yapılan röportaja yapılan yorumlarda belirgindir. Sığınmacıların TC vatandaşı olma olasılığı, "devlete sızma girişimi" olarak nitelenmiş ve "milletçe Suriyelilere haddini bildirmek gerek" sözleri ile nefret söylemini beslemek için kullanılmıştır (H1). Yorumlarda, iktidar partisinin sığınmacıları kendi seçmeni olarak gördüğü, bu nedenle vatandaş olacakları savı şu şekilde dillendirilmiştir:

\footnotetext{
"Yakında hepsine oy için vatandaşlık da verilecek"(H6)

"Benim gencecik askerim topraklarda şehit, bunlarınki benim ülkemde keyif. Oy uğruna değer mi?" (H6)
}

\section{Ne Yapmalı?}

Sosyal uyum sürecinin mihenk taşı, tarafların birlikte yaşama arzusu duymalarıdır (Guay, 2015, s. 9). Araştırma kapsamında incelenen okur yorumları sadece yerel toplumun görüşlerini yansıtıyor olsa bile sosyal uyumun ulaşılması zor bir hedef olduğunu anlamamız açısından yararlıdır. Haberleri yorumlayan okurların büyük çoğunluğu, yukarıdaki temaları oluşturan savları gerekçe göstererek Suriyeliler ile birlikte yaşamayı istemediklerini ifade etmiştir. Verilen sosyal yardımı kesmek, zorla ya da ikna ederek geri göndermek ve devletin soruna çözüm bulmak zorunda olduğu savları etrafında sığınmacılara karşı olumsuz tutuma sahip olduklarını dile getirmişlerdir. 


\subsection{Birlikte Yaşayamayız}

İncelenen yorumların çoğu, güçlü bir tonda sığınmacıların geri dönmesi gerektiği savını farklı gerekçeler ve stratejiler kullanarak yinelemiştir. Örneğin H6 kodlu habere yapılan yorumlarda "taş yerinde ağırdır" ve "gitmemeliler ne demek yahu? herkes kendi ülkesine dönmeli..." şeklinde bireyin doğduğu toprağa ait olduğu savına dayandırılarak birlikte yaşamak istenmediği belirtilmiştir. "Gitsinler de ülkemiz de rahat bir nefes alsın" (H6) "kesinlikle ülkemizden defolup gitsinler." (H1) örnekleri de yorum sahiplerinin sığınmacılarla ilişki kurmaktan kaçındıkları ve hatta rahatsız oldukları şeklinde yorumlanabilir.

Birlikte yaşamak ve sosyal uyumu kolaylaştırmak yerine sınır dışı etmek gerektiğini ileri sürenlerin çözüm önerilerinden biri devletin süreci kontrol altına alması, sığınmacıları kamplara ya da ülkelerine geri göndermesidir. "Türkiye'de Suriyeli istemiyoruz. Sayın cumhurbaşkanım, devlet büyüklerimiz, millet bıktı artık bunlardan"(H1)ve "Devlet önlemini almal, vatandaş kendi önlemini almaya kalkarsa sonuçları iyi olmaz" (H7)örneklerinde görüldüğü gibi...

Türkiye'de ve Avrupa'da Suriyeliler konusunda dile getirilen insâni yardım söyleminin de kontrol söylemiyle yan yana durduğu görülmektedir. Toplu sığınmanın başladığı andan itibaren uygulanan göç politikasına yönelik en büyük eleştiri, sığınmacıların kontrolü ve sınır güvenliği olmuştur. Dolayısıyla, uluslararası göç politikalarında devlet güvenliği ön plana çıkarken insan hareketliliği de güvenlikle ve kontrol söylemiyle doğrudan ilişkilendirilmektedir (Rumelili ve Karadağ, 2017, s. 69; Şimşek ve İçduygu, 2017, s. 6; Sirkeci, 2017, s. 21; Üstübici, 2017, s. 107). Bazı katılımcılar sığınmacıların zorla ülkelerine gönderilmesi gerektiğini "Kovun gitsinler."(H6) ve "Ya adam gibi güzel güzel göndereceksiniz, ya da bu millet tekme tokat atacak sınır ötesine!!!" (H6) gibi ifadelerle dile getirmiştir.

Geri dönmeye ikna edilebilecekleri $(\mathrm{H} 1)$ veya devletin sı̆̆ınmacıları kamplara gitmeye zorlaması (H1) diğer çözüm yolları olarak sunulmuştur."Devlet büyüklerimiz bunları aramızdan alsınlar. Mülteci kamplarına yerleştirsinler" (H1) örneğinde görüldügüü gibi...

Yorumların bir kısmında ise Suriyelilerin geri dönmek istememe nedeni, ekonomik koşullarının iyi olmasına ve Türkiye'de yararlandıkları sosyal yardımlara bağlanmıştır. Yardımın sonlandırılması durumunda geri dönecekleriileri sürülmüşstür:

"Olay bitince kesersin yardımlar, SGK numaralarını iptal edersin. Bak nasıl dönüyorlar..." (H6)

"Tamam, zorla yollayalım demedik. Kesin o paraları, diğer imkânlarn, zaten mecbur dönerler."(H6)

"Onları bir takım teşviklerle (bedava üniversite, doktor, hastane, ikinci eş olma, Arapça eğitim vb. imkânlarla) topraklarından soğutmamalısınız."(H6)

"Niye dönsünler ki? Ekmek bizden, su bizden! Yan gel Osman on dönüm bostan!"(H6)

\subsection{Birlikte Yaşayabiliriz}

Örneklem içerisinde yer alan az sayıda yorumda (86 adet) saldırgan ve nefret içeren cümlelere tepki olarak Suriyeli sı̆̆ınmacılara ilişkin olumlu tutum sergilenmiştir. Sığınmacıların lehine yazılan yorumlar, "biz de masum değiliz" (H8); "yabancı düşmanlığı, ırkçılık yapmayalım"(H4), her iki toplum "dini ve kültürel açıdan benzer özelliklere sahiptir" (H6) ve "nitelikli Suriye vatandaşları ülkemize katkıda bulunabilirler" (H2) savlarını yinelemektedir. Örneğin, Gaziantep'teki istismar vakası (H7) ile Suriyeli çocuk anneye (H5) ilişkin gelişmelerin aktarıldığı haberlerin altında "biz de masum değiliz"savını destekleyen, "sadece Suriyeliler yapmıyor ki, bizim milletimiz de yapıyor"; "sanki bizim doğuda farklı mı?" ve "(hastaneye gelen) 115 çocuktan 39'u Suriyeli. Diğerlerini ne yapacă̆ız?" yorumu yapılmıştır. Zaman zaman ırkçı bir üsluba bürünen ifadelere tepki olarak "vazifesini hakkıyla yapan bütün insanlar eşittir; 
işini iyi yaptıktan sonra dünyanın her tarafında iş bulabilmeli herkes" (H6); "arkadaşlar yabancı düşmanlığını bırakınız; doktor açı̆̆ımız var; bizim insanlarımız da göç ediyor başka ülkelere" (H6) yorumları yapılmıştır.

Suriyelilerle birlikte yaşama arzusunu beyan edenlerin gerekçelerinin başında "Adileşme bu kadar. Suriyelilerle kardeşiz biz" (H3) şeklinde kardeşliğin, özellikle "din kardeşliği"nin geldiği görülmektedir. "Suriyeliler bizim kardeşlerimiz, elhamdülillah"(H6); "Allah devletimizi korusun. Benim için Müslüman olması yeterli" (H4), "Helal olsun senin gibi din kardeşime. Keşke herkes senin gibi imkânsızı başarabilse..." (H2) cümleleri bu temanın altına toplanan yorumları özetlemektedir.Yorumların bir kısmında tarihsel atıflar aracılığıyla benzerlikler vurgulanmaya çalışılmıştır. Örneğin;

"...Ataları bizim atalarımızla koyun koyuna yatıyor, başta Çanakkale olmak üzere birçok yerde. Bir zamanlar aynı bayrağı̆n gölgesinde bulunmuşuz ama zamanın hâkim güçleri sınırları çizince el olmuşlar."(H6)

"Bundan 100 yıl önce Suriyeli dediğiniz insanlar bizim vatandaşımızdı. Suriyelilerin hepsine vatandaşlık verilmeli" (H3)

Suriyeli sığınmacılar içerisinde eğitim seviyesi yüksek olan, vergi vererek ülke ekonomisine katkı sağlayanların kalması gerektiğine ilişkin yorumlar göze çarpmaktadır. Suriyeli doktor istihdamına ilişkin habere yapılan yorumlar bu durumu örneklemektedir:

"Dilenen Suriyelidense böyle beyin göçü her zaman iyidir."(H4)

"Yetişmiş insanları ülkemize kazandırmak en doğru yaklaşımdır. Suriyeliler arasında iyi eğitimli, meslek sahibi insanları bugüne dek açı̆̆g çıkarıp adaptasyonlarımı sağlamamak en büyük hataydı." (H4)

"Adam ülkeye döviz kazandırmış. Sen ne yaptın bu ülke için?" (H2)

Yapılan araştırmalarda eğitim seviyesi yüksek olan Suriyelilerin Türkiye'de kalmak yerine üçüncü ülkelere geçmeye istekli oldukları görülmektedir (Erdoğan, 2014, s. 7). Suriyeli üniversite öğrencilerinin Türkiye'de "çifte vatandaşlık" statüsünden ziyade "ikamet müsaadesi" ile kalmak istedikleri Erdoğan'ın 2017 tarihli çalışmasında tespit edilmiştir (Erdoğan, Erdoğan, vd., 2017, s. 64).

Bazı yorumlarda ise Suriyelilerin yerel toplumun yapmak istemediği işleri yaptığı, kırsalda ucuz işgücü olarak çalıştıkları, bu sayede tarımsal ürünlerin şehirlerde daha uygun fiyatlı satılabildiği (H6) bu nedenle Suriyelilerin kalması gerektiği savı yinelenmiştir.

\section{Sonuç ve Öneriler}

Sosyal uyum, toplulukların birlikte yaşama arzusu duymaları ile başlar ve karşılıklı etkileşim yoluyla artarak devam eder. Bu araştırmada, Suriyeli sığınmacılarla ilgili haberlerin altına yazılan yorumlar, sosyal uyumun göstergeleri olarak düşünülerek incelenmiştir. Genel olarak değerlendirildiğinde yorum sahiplerinin büyük çoğunluğunun (\%86), Suriyelilerin Türkiye'ye kalıcı olarak yerleşmeleri düşüncesinden rahatsızlık duyduğu görülmektedir. Suriye'de savaş bittiği halde sığınmacıların Türkiye'de sosyal yardımdan yararlandıkları ve rahat yaşadıkları için geri dönmek istemediklerine dair birçok yorum paylaşılmıştır. Dışlayıcı ve ön yargılar barındıran, zaman zaman nefret içeren üslubun altında yatan sebebin "misafir söylemi" olduğu belirlenmiştir. Ev sahibinin sabrını zorlayan "misafirler"in kalma süresinin uzaması, her türlü ayrımcı söylemin altında temel gerekçe olarak kullanılmıştır. Bu ayrımcı nefret içeren söylem, "Biz/Onlar" dikatomisi ile meşrulaştırılmıştır. Suriyeliler "cahil, suçlu, kanun tanımaz, güvenilmez, sorun çıkaran, nankör" gibi ifadelerle tanımlanmış, Türkiye'nin güvenliği için tehdit oluşturdukları ve birlikte yaşamanın mümkün olmadığı ileri sürülmüştür. 
Sosyal uyum konusunda olumlu olarak nitelenebilecek çok az sayıda yorum, örneklem içerisinde yer bulabilmiştir. Bu yorumlarda dini ve kültürel benzerlikler ile tarihsel bağlara atıfta bulunulduğu görülmektedir. Dahası, olumlu yorumlar daha çok eğitim seviyesi yüksek olan ve ekonomiye katkı sağlayabileceği düşünülen 'nitelikli' Suriyeliler bağlamında yapılmıştır.

Araştırmada incelenen okuyucu yorumlarından anlaşılmaktadır ki, sosyal uyumun sağlanabilmesi için ön koşul mevcut ön yargıların, sosyal dışlamanın ve ayrımcılığın deşifre edilmesi, nedenlerinin tespit edilmesi, önlemeye yönelik tedbirler alınmasıdır. Bu noktada Suriyelilere ilişkin kalıpyargılar (doğru bilinen yanlışlar) önemli bir mücadele alanı oluşturmaktadır. Üniversiteye sınavsız giriş, ücretsiz belediye otobüslerinden faydalanma gibi gerçek dışı bilgilerin yayılmasının önüne geçilmesi önemlidir. Dahası, özellikle sosyal yardımlar konusunda kaynağın daha açık ve somut olarak ifade edilmesine ihtiyaç duyulmaktadır. Anlaşılan odur ki, aynı koşullarda yaşayan iki bireyden birinin desteklenirken diğerinin hizmetlerin dışında bırakılması eşitsizlik ve adaletsizlik hissiyatına yol açabilmekte, bu durum ise yerel toplum ile Suriyeliler arasındaki sosyal mesafenin artmasına sebep olmaktadır. Dolayısıyla, dış fonlarla Suriyelilere sağlanan olanak ve hizmetlerin Türkiye'de yerel toplumun yoksul kesimlerine de sağlanması, karşılıklı sağduyunun artması ve ön yargıların azalması açısından önem taşımaktadır.

\section{Kaynakça}

AFAD. (2014). Türkiye'deki Suriyeli kadınlar: Başbakanlık Afet ve Acil Durum Yönetimi Başkanlığı.

Ardıç Çobaner, A. (2015). Çocuk hakları bağlamında Suriyeli mülteci çocukların haberlerde temsili. Marmara İletişim Dergisi, 24, 27-54.

Buz, S. ve Aygüler, E. (2017). Amartya Sen'in kapasite-yapabilirlik yaklaşımı bağlamında Türkiye'de yoksulluk durumu. Journal of Academic Value Studies, 15(3), 177-189.

Çağlar, İ. ve Özkır, Y. (2014). Suriyeli mültecilerin Türkiye basınında temsili. Middle East Yearbook/Ortadoğu Yıllığı.

Çuhadar Gürkaynak, E. (2012). Toplumsal temas: Önyargı ve ayrımcılığı önlemek için bir sosyal değişim aracı olarak kullanılabilir mi? Ayrımcılık: Çok Boyutlu Yaklaşımlar, 255-267.

Deleuze, G., ve Guattari, F. (1990). Kapitalizm ve Şizofreni 1-Göçebebilimi İncelemesi: Savaş Makinası. Çeviren: Ali Akay, Bağlam Yayınları, İstanbul.

Doğanay, Ü. ve Çoban Keneş, H. (2016). Yazılı basında Suriyeli 'mülteciler': Ayrımcı söylemlerin rasyonel ve duygusal gerekçelerinin inşası. Mülkiye Dergisi, 40(1), 143-184.

Dursun, O. (2012). Medyada gerçekliğin inşasında okurun rolü (Hürriyet Gazetesi okur yorumları üzerine bir analiz). Hitit Üniversitesi Sosyal Bilimler Enstitüsü Dergisi, 5(2), 1-22.

Efe, İ. (2015). Türk basınında Suriyeli sığınmacılar. İstanbul: Siyaset, Ekonomi ve Toplum Araştırmaları Vakfı (SETA).

Cinel, E. A. (2019). Türkiye ekonomisinin kırılgan yapısı-fragile structure of Turkish economy. Mehmet Akif Ersoy Üniversitesi Sosyal Bilimler Enstitüsü Dergisi, 10(23), 57-66.

De Jong, G. F. (2000). Expectations, gender, and norms in migration decision-making. Population studies, 54(3), 307-319. 
Duncan, G. J., ve Newman, S. J. (1976). Expected and actual residential mobility. Journal of the American Institute of Planners, 42(2), 174-186.

Erdoğan, M. M. (2014). Türkiye'deki Suriyeliler: Toplumsal kabul ve uyum araştırması. Ankara: Hacettepe Üniversitesi Göç ve Siyaset Araştırmaları Merkezi (HUGO).

Erdoğan, M. M. (2017). Suriyeliler barometresi 2017: Suriyelilerle uyum içinde yaşamın çerçevesi Yönetici özeti, değerlendirme, politika önerileri.

Erdoğan, M. M., Erdoğan, A., Yavcan, B., Mohamed, T. H., Kavukçuer, Y. ve Sancı, G. (2017). Elite dialogue: Türkiye'deki Suriyeli mülteci akademisyen ve üniversite öğrencilerinin durumu, sorunları ve beklentileri araştırması 2017.

Erdoğan, M. M., Şener, B., Sipahioğlu, E., Kavukçuer, Y. ve Yılmaz Başçeri, E. (2017). Kopuş'tan uyum'a kent mültecileri: Suriyeli mülteciler ve belediyelerin süreç yönetimi: İstanbul örneği: Marmara Belediyeler Birliği Kültür Yayınları.

Erdoğan, M. M. ve Ünver, C. (2015). Türk iş dünyasının Türkiye'deki Suriyeliler konusundaki görüş, beklenti ve önerileri. Ankara: Türkiye İşveren Sendikaları Konfederasyonu.

Eren, A. S. ve Tunç, A. (2018). Kahramanmaraş'taki suriyeli göçmenlerin hayattan ve kamu hizmetlerinden memnuniyet düzeylerinin ölçümüne yönelik bir alan çalışması. ASSAM, 5(12), 21-31.

Esnafı bitiren ayrıcalık. (29 Mayıs 2014). Sözcü Gazetesi. 15.11 .2019 tarihinde https://www.sozcu.com.tr/2014/gunun-icinden/esnafi-bitiren-ayricalik-520091/ adresinden alindi.

European Commission. (2005). Study on immigration, integration and social cohesion: Final report. İçinde: European Commission Employment and Social Affairs DG (Ed.): Focus Consultancy Ltd., Erasmus University Rotterdam Faculty of Social Sciences.

Fielden, A. (2008). Local integration: an under-reported solution to protracted refugee situations. UNHCR, Policy Development and Evaluation Service.

Friedkin, N. E. (2004). Social cohesion. Annu. Rev. Sociol., 30, 409-425.

Göç İdaresi Genel Müdürlüğü. (2017). 2016 Türkiye göç raporu. Ankara: T.C. İçişleri Bakanlı̆̆1 Göç İdaresi Genel Müdürlüğü Göç Politikaları ve Projeleri Dairesi Başkanlığı.

Göç İdaresi Genel Müdürlüğü. (2019). Geçici koruma istatistikleri. 15.11.2019 tarihinde https://www.goc.gov.tr/gecici-koruma5638 adresinden alınmıştır.

Guay, J. (2015). Social cohesion between Syrian refugees and urban host communities in Lebanon and Jordan: World Vision.

Gülyaşar, M. (2017). Suriyeliler ve vatandaşlık: Yerel halk ve Suriyeli sığınmacılar çerçevesinde bir değerlendirme. Uluslararası Toplum Araştırmaları Dergisi, 7(13), 678-705.

Hall, S. (2001). Encoding/decoding. Media and cultural studies: Keyworks, 2.

Hewstone, M. ve Swart, H. (2011). Fifty-odd years of inter-group contact: From hypothesis to integrated theory. British Journal of Social Psychology, 50, 374-386.

Human Rights Watch. (2018). Syria: Events of 2018. 14.11.2019 tarihinde https://www.hrw.org/world-report/2019/country-chapters/syria adresinden alınmıştır. 
İçduygu, A. (2017). Türkiye'deki Suriyeli sığınmacılar: "Siyasallaşan" bir sürecin analizi. Toplum ve Bilim, 140, 27-41.

IOM. (2017). Integration and social cohesion: Key elements for reaping the benefits of migration Global Compact Thematic Paper: International Organization for Migration.

Kan, K. (1999). Expected and unexpected residentialmobility. Journal of Urban Economics, 45, 72-96.

Kap, D. (2014). Suriyeli mülteciler: Türkiye'nin müstakbel vatandaşları. Akademik Perspektif, 30-35.

Karataş, M. (2015). Türk yazılı basınında Suriyeli sığınmacılar ile halk arasındaki ilişkinin incelenmesi. Göç Araştırmaları Dergisi, 1(2), 112-151.

Karataş, K., Demiröz, F., Aygüler, E., Ayalp, M. Ç. ve Bolgün, C. (2018). Türk Kızılayı Ankara Toplum Merkezinden hizmet alan Suriyeliler: Sorun, gereksinim, beklenti ve kurum memnuniyetleri. Ankara: Türk Kızılayı.

Kardeş, S., Banko, Ç. ve Akman, B. (2017). Sosyal medyada Suriyeli sığınmacılara yönelik alg1: Bir sözlük değerlendirmesi. Göç Dergisi, 4(2), 185-200.

Khalaf, S. ve Ilgar, R. (2017). Suriyeli mülteciler ve Türkiye'de mülteci sorunu. Türk Sosyal Bilimler Araştırmaları Dergisi, 2(2), 40-52.

Kizılkaya, H. (18 Temmuz 2014). 10 maddede Suriyeli Sorunu'muz. Hürriyet Gazetesi. 15.11.2019 tarihinde http://www.hurriyet.com.tr/yazarlar/emre-kizilkaya/10-maddedesuriyeli-sorunumuz-26711968 adresinden alınmıştır.

Kuş, O. (2016). Dijital nefret söylemini anlamak: Suriyeli mülteci krizi örnek olay1 bağlamında BBC World Service :Facebook sayfasına gelen yorumların metin madenciliği tekniği ile analizi. İstanbul Üniversitesi İletişim Fakültesi Dergisi, 97-122.

McHugh, K. E. (1984). Explaining migration intentions and destination selection. The Professional Geographer, 36(3), 315-325.

Özdemir, S. (2007). Küreselleşme Sürecinde Refah Devleti (2. Bask1 ed.). İstanbul: İstanbul Ticaret Odası Yayınları.

Öztürk, M., ve Çetin, B. I. (2009). Dünya'da ve Türkiye'de yoksulluk ve kadınlar. Journal of Yasar University, 4(16).

Landale, N. S., ve Guest, A. M. (1985). Constraints, satisfaction and residential mobility: Speare's model reconsidered. Demography, 22(2), 199-222.

Maslow, A. H. (1943). A theory of human motivation. Psychological review, 50(4), 370.

Max-Neef, M. A. (1992). Human scale development: conception, application and further reflections (No. 04; HC125, M3.).

Neuman, W. L. (2009). Toplumsal araştırma yöntemleri: Nitel ve nicel yaklaşımlar (Sedef Özge, Çev.). İstanbul: Yayınodası.

Özalp, M. (2019). The 'ceasefire' in Syria is ending - here's what's likely to happen now. The Conversation: Academic Rigour, Journalistic Flair, http://theconversation.com/theceasefire-in-syria-is-ending-heres-whats-likely-to-happen-now-125492 adresinden alınmıştır. 
Paksoy, A. F. ve Şentöregil, M. (2018). Türk basınında Suriyeli sığınmacılar: İlk beş yılın analizi (2011-2015). Selçuk İletişim, 11(1), 237-256.

Rettberg, J. W. ve Gajjala, R. (2016). Terorists or cowards: Negative portrayals of male Syrian refugees in social media. Feminist Media Studies, 16(1), 178-181.

Rudiger, A. ve Spencer, S. (2003). Social integration of migrants and ethnic minorities: Policies to combat discrimination. Paper presented at the Conference on the Economic and Social Aspects of Immigration Organized by the European Commission and OECD.

Rumelili, B. ve Karadağ, S. (2017). Göç ve güvenlik: Eleştirel yaklaşımlar. Toplum ve Bilim, $140,69-92$.

Saggar, S., Somerville, W., Ford, R. ve Sobolewska, M. (2012). The impacts of migration on social cohesion and integration: Final report: Migration Advisory Committee.

Sapancali, F. (2007). Türkiye'de işgücü piyasasi, sorunlar ve politikalar. Türk Ağır Sanayii ve Hizmet Sektörü Kamu İşverenleri Sendikası (TÜHİS) İş Hukuku ve İktisat Dergisi, 21(2-3), 8-30.

Şimşek, D. (2017). Göç politikaları ve insan güvenliği: Türkiye'deki Suriyeliler örneği. Toplum ve Bilim, 140, 11-26.

Şimşek, D. ve İçduygu, A. (2017). Giriş: Uluslararası göç, politika ve güvenlik. Toplum ve Bilim, 140, 6-10.

Sirkeci, İ. (2017). Bir güvensizlik ülkesi olarak Türkiye'nin mültecileri, Suriyeliler ve Türk mülteciler. Göç Dergisi, 4(1), 21-40.

Suriye'de bombalı araç inflak etti! (22 Ocak 2019). Hürriyet Gazetesi. 15.11.2019 tarihinde http://www.hurriyet.com.tr/dunya/son-dakika-suriyede-bombali-arac-panigi-41091108 adresinden alındı.

Süleymanov, A. (2017). Suriyelilerin Türk toplumunda toplumsal uyum ve sosyal kabul düzeyi. Türk Yurdu Dergisi, 361, 27-30.

Üstübici, A. (2017). Türkiye'de göç politikalarının dönüşümü: Yasadışılığın uluslararası üretiminden makbul yabanciya? Toplum ve Bilim, 140, 106-121.

Van Dijk, T. A. (2000). Ideology and discourse. PompeuFabra University, Barcelona.

Van Schaik, R. W. (2015). Visual representations of (Syrian) refugees in European newspapers. (One-Year Master), Malmö University, Malmö.

Yıldırımalp, S. ve İyem, C. (2017). Suriyeli sığınmacıların toplumsal kabul ve uyum sürecine ilişkin bir araştırma. Bilgi Sosyal Bilimler Dergisi, (2), 107-126.

Yıldız, U. ve Sert, D. (2017). Göçün jeopolitiği ve Türkiye'nin coğrafi kısıtlaması üzerine farklı bir yorum. Toplum ve Bilim, 140, 93-105. 